\title{
磁性材料・磁気デバイスにおける微細構造制御と機能発現 Control and Manipulation of Microstructure in Magnetic Materials for Functional Devices
}

\author{
北本 仁孝 \\ Yoshitaka KITAMOTO \\ 東京工業大学 \\ Tokyo Institute of Technology
}

本特集では，現在の磁性材料・磁気デバイスの研究開発に おいて重要な微細構造の創製・組織制御・評価技術と，その ような微細構造組織と応用につながる機能との相関に関する

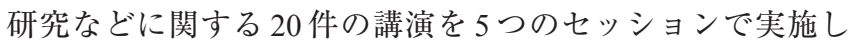
ました。

今回の講演特集においてもハードからソフト磁性, 新規磁 性材料に関する多様な講演で構成され, 企業, 国研, 大学と 幅広い講演者, 参加者を集めました，立見が出るほどの熱の こもった会場は，引き続きこの分野への関心が高いことを示 す証と考えます。

第 1 のセッションはハード磁性材料の発表で構成されて いたが，今回はこれまでと比較して少なかった。引き続き $\mathrm{SmFeN}$ 系材料の講演が多く，圧延加工と磁場による配向制 御を組み合わせて, Sm-Fe-N 異方性薄板磁石の実現可能性に ついて検討した結果，この講演特集のテーマである微細構造 制御における Zn ボンド磁石の高保磁力化のメカニズム解析 が発表された。 また, 高飽和磁化, 高異方性磁界を有する ハード磁性材料として期待される $\mathrm{ThMn}_{12}$ 構造を有する希土 類-鉄二元合金化合物を目指した Y-Fe 合金の講演があった.

フェライトについては, Mn 置換 $\mathrm{Sr}-\mathrm{M}$ 型フェライトにおけ る $\mathrm{Mn}$ 占有率の評価として詳細な中性子回折の Rietveld 解析 が報告された.

第 2 セッションでは，フェライト微粒子，薄膜についての 講演が行われた。粒子径に着目した, $\mathrm{MnZn}$ フェライトの粒 子径評価手法に関して, 溶液プロセスによるマグネタイトナ ノ粒子の制御に関して，2 件の報告があった。続いて，六方 晶フェライト薄膜作製について，高周波デバイスへの応用が 期待される $\mathrm{M}$ 型， $\mathrm{Y}$ 型フェライト薄膜の有機金属分解法に よる作製とその評価結果が報告された.

第 3 セッションでは引き続き微粒子と薄膜の研究報告が なされた。微粒子においては, Mn 置換によるCoフェライ 卜微粒子における高保磁力と共存する高飽和磁化の実現に 向けた報告, マグネタイトナノ粒子を $\mathrm{CaH}_{2}$ により低温で還
元して Feナノ粒子を得る手法に関する報告がなされた。薄 膜においては，スピントロニクスへの応用を目標としたパ ルスレーザー堆積法による四重ペロブスカイト型酸化物薄 膜，垂直磁気記録媒体への応用を目指したスパッ夕法による $\mathrm{NdFeB}$ 薄膜に関する発表がなされた。

第 4 セッションではフェライトより高い飽和磁束密度が要 求されるパワーエレクトロニクス用デバイスへの応用が想 定される， $\mathrm{Fe}$ 系ナノ結晶，アモルファス微粒子及び粉末に 関する講演が行われた。その中で，Mn フェライトを水素還 元する手法による Fe-Mn 合金において，低保磁力化のメカ ニズムを電子顕微鏡により解析した結果が報告された。続く $\mathrm{Fe}$ 基合金軟磁性材料については，熱処理による非晶質から ナノ結晶の生成状態と飽和磁束密度, 保磁力, 透磁率等の軟 磁気特性との件系を調べる講演が続いた。

第 5 セッションでも $\mathrm{Fe}$ 系磁性材料に関する講演が続いた が, 粉末よりも圧粉磁心や薄帯といった素材に主眼を置いた ものであった．添加元素，あるいは微粒子表面被覆の効果が 議論される講演の後, 圧粉磁心を適用したモー夕の効率化に 関する講演でセッションを終えた

今回の講演特集では，これまで多数の講演のあったハード 磁性材料に関するものが減少し，代わりに前回少なかったソ フト磁性に関する講演が増加しました．次回は両方の講演と ともに新しい視点からの材料, デバイスに関する講演が集ま ることを期待しています.

これまで同様に, 多様な講演がなされ大盛況のセッション を実施できましたのは，講演者，参加者の皆様のおかげと感 謝申し上げます。学生や若手研究者の発表も多く, この分野 でますます活発な研究開発が続き, 活性化されたセッション の開催により，本協会への貢献できるものと考えます。その ために, 今後も広く磁性材料・磁気デバイス分野を俯瞰する ことのできる講演特集を企画してまいります．なお，本講演 特集のセッションより 2 件の優秀講演発表賞が選出されまし た.今後も若手研究者の精力的な発表を期待します. 